\title{
EQUiLIBRIUM
}

Quarterly Journal of Economics and Economic Policy

2014 VOLUME 9 ISSUE 4, December

p-ISSN 1689-765X, e-ISSN 2353-3293

www.economic-policy.pl

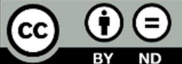

Tyshchenko, M. (2014). Methodological Problems of Modern Political Economy Subject. Equilibrium. Quarterly Journal of Economics and Economic Policy, 9(3), pp. 103-110, DOI: http://dx.doi.org/10.12775/EQUIL.2014.027

Maria Tyshchenko*

Vadim Getman Kyiv National Economic University, Ukraine

\section{Methodological Problems of Modern Political Economy Subject}

\section{JEL Classification: $B 1 ; B 4$}

Keywords: new political economy; policy analysis; subject of political economy

\begin{abstract}
The article addresses the problem of new political economy as grand (if imperfect) synthesis of various strands. Exploring different approaches reveals a set of the problems concerning the rise of economic society. We show in the article through the classical approach that political economy responds to and contributes to economics, so far as the older sense of politics is concerned. Most approaches to political economy treat the private sector as the primary arena. It sets agendas and ultimately governs outcomes. The idea of a collective or public reality different in nature from the system of private interests holds little appeal for political economy. In our view, the main difficulty of political economy, common to different approaches, lies in the tendency to gloss over the separateness of the two spheres, the economic and the political one, absorbing one into the other. The main topic of our survey is the importance of understanding and appreciating the categorical distinction between politics and economics, and the dangers of making one or the other dominant in both realms.
\end{abstract}

(C) Copyright Institute of Economic Research \& Polish Economic Society Branch in Toruń Date of submission: March 14, 2014; date of acceptance: August 15, 2014

* Contact: tishenko19@ukr.net, Vadim Getman Kyiv National Economic University, 54/1 Prospect Peremogy 03680 Kyiv Ukraine 


\section{Maria Tyshchenko}

\section{Introduction}

During its long lifetime the category "Political economy" has undergone a range of various meanings. It is useful to set the newer usage of this term in its wider historical context. It will also help to legitimate the adjective which is new for the enterprise that I am discussing.

For Adam Smith, political economy was a science of managing nations' resources in order to generate wealth. For Marx it was the way the ownership of the means of production influences historical processes. In the $20^{\text {th }}$ century "Political economy" had a contradictory meaning. On the one hand, it was viewed as an area of study (the interrelations between economics and politics) while on the other hand, as a methodological approach. Even the methodological approach was divided into two parts - the economic approach (often called public choice), emphasizing individual rationality, and the sociological approach, where the level of analysis tended to be institutional. New political economy has become one of the most active research areas in the last decades. Developed on the basis of the public choice school's studies, rational expectations, macroeconomics and game theory political economy has taken the next step by including rational voters, parties and politicians in the modules. The "new" political economy is not however just a reservation of an earlier approach to the economics. Nowadays it is characterized by a strong interest in the way politics affect economic outcomes. The New Political Economy is about expanding the domain of economic policy analysis and hence enhancing its relevance.

The aim of the New Political Economy is to understand the important issues that arise in the policy and economy sphere. The main concern is to extend the competence of economists to analyze issues that require some facility with economic and political decision making. At the margin, the New Political Economy reverses the split that occurred between the disciplines of economics and political science at the end of the nineteenth century. This article is a selective and personal view of some of the themes in the literature. The main objective of the article is to provide an outlook on the retrospective analyze of political economy.

\section{Literature review}

The New Political Economy borrows ideas and develops themes from all of its historical predecessors:

1. Classical Political Economy,

2. International Political Economy,

3. Comparative Political Economy (various political economies of...) 
4. New PE, Political Economics, Analytical PE, Positive PE, Public Choice.

The new political economy which is defined more by its way of approaching this particular issue and by its use of formal and technical tools of modern economic analysis investigates the importance of politics for economics. With the division of economics and political science into district disciplines economists abstracted from political and institutional factors. The desire for developing methodological progress and more rigorous basis for economic analysis was an important motivation in this separation. The development of neoclassical economics stressed optimization by consumers and firms object to well-defined constraints and a market environment, deliberately downplaying more amorphous political factors. Those determinants of economic outcomes are easily formalized in this choicetheoretic framework stressed in the development in the field of neoclassical economics those which are not easily formalized were seen largely in the province of other disciplines.

\section{Chronology of transformation of the category "political economy"}

Classical political economy engaged with broader interests which are now refer to economics. In the Book "Wealth of Nations" Adam Smith was engaged in the study of political economy in the narrower sense of the modern lecture. He was keenly aware that effective government is involved in dealing with incentives inside government. He was, however, not preoccupied with the interplay between democratic institutions and the economy, although this is not particularly surprising considering the time when he was writing it.

For Ruskin, political economy was not a special science beyond the interest and understanding of the general citizen, but rather something that we all needed to be acquainted with; it was knowledge for social progress. Indeed, without this knowledge being available to individual social actors, Ruskin's political-ethical project is difficult to follow. Of course, Ruskin was not a political economist in the traditional understanding of the term, and he often distanced himself from being identified as such. In the preface to The Political Economy of Art, Ruskin notes that he has "never read any author on political economy, except Adam Smith, although later it becomes clear that he has also read J. S. Mill's and David Ricardo's work. This denial is best regarded as a rhetorical distancing from a perceived economic/rational political economy that Ruskin saw dominating the depiction of 
society, rather than as an accurate depiction of his reading habits (Ruskin, 2010, p. 204).

The term political economy continued to be used in the discussions of comparative economic systems - particularly in debates about the relative merits of socialism and capitalism. This kind of political economy was preserved by Marxist thinkers. But it was also evident in the writings of important Austrian thinkers, such as Hayek and Schumpeter.

In continental Europe, the schism between economics and politics was less marked than in the English-speaking world. This was particularly clear in the field of public finance which remained imbued with law and political science. But it was not until the post-war period with the creation of the field of Public Choice when these ideas were systematized into a body of understanding integrated with mainstream economics. The key contributors to this enterprise were Buchanan and Tullock, whose book The Calculus of Consent from 1962 provides a landmark analysis of problems of logrolling and implications of democratic governance for taxation and public expenditure.

Downs (1957) conducted a rapid change in the development of political economy. The book was filled with many important ideas, but the one that caught on most strongly among economists was his justification of the idea that politics would converge to the preferences of the median voter. Downs described politics in the language of competing firms called "parties" where customers were voters. He observed that if parties care only about winning, then they will have an incentive to converge to the centre - specifically the median voter. Similar ideas were also developed in Black (1958) who recognized the importance of preference restrictions to this prediction.

The classical tradition lost its place as the dominant approach in the economics to the marginalist framework of neoclassical economics, later evolving into the current mainstream approach whose views exact prediction through mathematical modeling as the defining feature of a scientific discipline. The works of Sraffa and Sen are complementary, each of them provides an alternative multidimensional conception to replace a key analytical component of mainstream economics: Sraffa proposes an alternative to the neoclassical production function, and Sen suggests an alternative to the neoclassical utility function in the analysis of behavior and welfare (Martins, 2011, p. 131).

Alt and Shepsle defined political economy as the study of rational decisions in the context of political and economic institutions, stressing explicit micro foundations based on rational actors (Alt, 1985, p. 1016).

The separation of society into an "economy" and "politics" does not flow directly or inevitably out of either of these two approaches considered so far. The idea of the economy as a social and historical specific institution 
is nonetheless an important one. When we speak about economy we already assume the existence of separable entity, a sphere, a moment of the whole in the Hegelian sense, a distinct set of relations between persons not in the essence of politics or family. This usage parallels of the historical emergence of the economy are investigated as separate institutions. Karl Polanyi more than any other contemporary thinker has drawn our attention to this aspect of modern social organization.

One result of placing emphasis on economic calculation is that the economics tends to dominate. The economic approach explains what we do and why we do it. Politics simply describes the context. If we wish to explain politics, we need to think in terms of economics. This dominance of economics expresses an important and enduring theme of political economy as we suggest. Political economy is about interrelation between economy and policy.

Aspects of the New Political Economy. Modern economic analysis is used not just in the format sense of mathematical approach, but also as a conceptual viewing of political phenomena in terms of optimization, incentives and so on. The relative novelty of political economy in its current form may cause this problem more debating. New political economy is not an insightful formalization on the obvious. Recent research has also been criticized for being too broadly seen, trying to cover everything, with widely differing degrees of success.

\section{Characteristics of new political economy}

\section{Theoretical Eclecticism}

The New Political Economy has not solved the problem of studying political competition in the absence of a Condorcet winner. But it has kept this issue firmly in the background. There are some new modeling approaches, but the literature has not tried to build around any dominant theoretical paradigm. However, a few key ideas are gaining currency. This idea is a key insight of Shepsle and Weingast (1981) who discuss how restrictions in the structure of proposal-power within a legislature can be used to generate a stable point in a multi-dimensional policy space in which no winner may exist. Roemer (2001) restricts proposal-power by modeling withinparty conflict. Such restrictions improve the odds of developing a model that predicts an equilibrium outcome in a particular policy context, providing a basis for empirical analysis. Restricting proposal power is also at the heart of the agenda-setter model of Romer and Rosenthal (1978). 


\section{A basis of new paradigm}

When a transition is made to a "neoinstitutional" environment, there is no denying the fact that the economic problem changes radically from the neoclassical concept. What happens is that decision makers find themselves in a quite different position with respect to the things traditionally assumed to be data.

That is, individuals are not "fully informed", as in the neoclassical model of general equilibrium. Rather, each individual has only partial knowledge of the options known to the society as a whole. In other words, it's no longer possible to assume that each decision maker has perfect information concerning all existing technological options, the true properties of every commodity, and so on. Moreover, at each cross sectioned time, each person's knowledge endowment or information structure tends to be somewhat different from those of other. The subject data, on the basis of which individual decision makers actually take action, are quite distinct from what might be called the objective data of the system. The latter are the data that are known in full only to the total collectivity of decision makers. The reinterpretations just noted are essential, but a satisfactory neoinstitutional model must take other data into account. It's not appropriate to ignore institutional arrangements or to assume that institutions are merely neutral in their effect on economic behavior. We know that institutions exert powerful influence on activity by determining both the structure of incentives and, along with technology, the magnitudes of transaction costs.

\section{Theory Meets Data}

The New Political Economy emphasizes empirical testing with three main sources of data being used. Firstly, there are many studies that use crosscountry data. Secondly, there are studies that exploit variation within countries, particularly across sub-national jurisdictions. This suffers from some of the problems discussed in the context of cross-country studies, since regions may be verified for cultural, economic and social reasons which are difficult to control for. The fact that many institutions remain fixed over time is also an issue. Finally, there is scope for collecting more data sets to examine specific policy issues.

\section{Comparative Institutional Analysis}

One of the central themes in the New Political Economy is developing theoretical and empirical implications of alternative institutional arrangements for making political choices. Institutions can be modeled following 
Douglass North as humanly devised constraints that shape social interaction or sometimes simply "the rules of the game". Comparative institutional analysis is also a place where complexity and subtlety can be brought in to capture the ways in which institutions work.

\section{Importance of Information}

"I hope to show that information economics represents a fundamental change in the prevailing paradigm within economics" (Stiglitz, 2002, p. 501). One of the central advances in economic theory in the past fifty years has been the development of tools for studying situations where individuals interact in situations in which information is imperfect. Information provision of this form is being studied increasingly by the New Political Economy and the emerging evidence suggests that the outcomes of the policy are affected by media activity.

\section{Dynamics}

Public resource allocation has both short- and long-term effects on the economy. One distinctive feature of the New Political Economy is the attention it pays to the dynamics of politics and economics, i.e. the evolution of economies and policies over time. A key aspect of the democratic political life is that governments are typically short-lived, while the consequences of many policies are not.

\section{Specificity}

A lecture such as this is not the place to review the voluminous of recent literature in the field of political economy (Besley, 2007, p. 581).

The New Political Economy rises to specific challenges. At a broad level, it is looking behind the institutions that generate policy outcomes. While this occasionally results in a more conservative appraisal of the capacity for government intervention, it also gives a way of thinking about how to make government intervention more effective. The New Political Economy occasionally engages in debates about grand issues such as the role of states versus markets and the differences between democracy and autocracy. However, a lot of the work is focused on how the institutional details of political structure matter for policy outcomes «in the small». 


\section{Conclusions}

The New Political Economy is not about economic imperialism. The aim is to generate new, policy-relevant insights, particularly in the areas where economists may have a comparative advantage. What we learn is complements rather than substitute's knowledge generated in other branches of the social sciences. Nowadays, this is a reasonable ambition at least at the intersection of economics and politics. The New Political Economy is about expanding the domain of economic policy analysis and hence enhancing its relevance. We have made good progress in finding ways to integrate politics and economics to help us think about important problems.

We view political economy as a grand (if imperfect) synthesis of these various standards. In our view, political economy is the methodology economics is applied to the analysis of political behavior and institutions. As such, it's not a single unified approach but a family of approaches. The institutions are no longer ignored, but instead are often the subject matter of investigation. This approach incorporates many of the issues of concern to political sociologists. Because of the fact that political behavior and institutions are themselves a subject of a study, politics also becomes the subject of a political economy. All of this is tied up together by a set of methodologies, typically associated with economics, should be considered as a political science itself.

\section{References}

Alt, J. E. (1985). Political parties, world demand, and unemployment: domestic and international sources of economic activity. American Political Science Review, 79.

Besley, T. (2007). The new political economy. Economic Journal, 117.

Etzioni, E. (2010). A New Political Economics - and Political Economy. Critiques of Economics Challenge, 53(3).

Martins, N. (2011). The Revival of Classical Political Economy and the Cambridge Tradition: From Scarcity Theory to Surplus Theory. Review of Political Economy, 23(1).

May, C. (2010). John Ruskin's Political Economy: 'There is No Wealth but Life'. British Journal of Politics and International Relations, 12.

Persson, T., \& Tabellini, G. (2000). Political economics: Explaining economic policy. Massachusetts: Massachusetts Institute of Technology.

Polanyi, K. (1944). The transformation. New York: Rinehart.

Stiglitz, J. E. (2002). Information and the Change in the paradigm in economics. American Economic Review. 92. 